"Does contract size matter for price discovery and risk management in stock index futures?"

$\begin{array}{ll}\text { AUTHORS } & \begin{array}{l}\text { Sangram Keshari Jena } \\ \text { Ashutosh Dash }\end{array}\end{array}$

Sangram Keshari Jena and Ashutosh Dash (2016). Does contract size matter for $\begin{array}{ll}\text { ARTICLE INFO } & \text { price discovery and risk management in stock index futures?. Investment } \\ \text { Management and Financial Innovations, 13(3), 62-74. }\end{array}$

doi:10.21511/imfi.13(3).2016.05

DOI

http://dx.doi.org/10.21511/imfi.13(3).2016.05

RELEASED ON

Tuesday, 23 August 2016

JOURNAL

"Investment Management and Financial Innovations"

FOUNDER

LLC "Consulting Publishing Company "Business Perspectives"

NUMBER OF REFERENCES

0

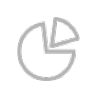

NUMBER OF FIGURES

0

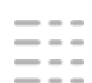

NUMBER OF TABLES

0

(C) The author(s) 2023. This publication is an open access article. 
Sangram Keshari Jena (India), Ashutosh Dash (India)

\title{
Does contract size matter for price discovery and risk management in stock index futures?
}

\begin{abstract}
In an effort to increase the liquidity and accessibility to the investors, National Stock Exchange of India (NSE) had reduced contract size of its Nifty index futures two times from 200 to 100 and, subsequently, to 50 units. How does this change in contract size of index futures impact the informed and hedge based trading, thereby contributing to the twin objectives of price discovery and risk management, respectively? VAR model is applied to daily return volatility, volume and open interest to study the impact. Significant feedback relationship between volume and volatility following the reduction in contract size establishes the informational trading and price discovery. However, no causality from volatility to open interest implies contract size is not a determinant of hedging. But significant causality from open interest to volatility is establishing the non-informational and liquidity trading. So stock exchanges should consider the appropriate lot size before going for introducing new futures contract.
\end{abstract}

Keywords: VAR, price discovery, risk management, granger causality, variance decomposition, impulse function. JEL Classification: G12, G14.

\section{Introduction}

Contract size is one of the important attributes of the futures contract. Because not only too large contract will inhibit small players to enter the market, but also making hedging difficult for big players. Again, changing contract size also impacts the relationship amongst the futures return volatility, and it's trading activity measured by volume and open interest. Because any change in market microstructure due to regulatory changes, it impacts the dynamics of the volatility, volume and open interest (Watanabe, 2001). This dynamic relationship plays important role in asset pricing and portfolio insurance and return predictability in futures market. Wang and $\mathrm{Yu}$ (2004) in their study in 24 US futures market confirm that short term profits on a contrarian portfolio (buying past losers and selling past winners) can be predicted from past trading activity variables such as volume and open interest. According to them, lag volume and lag open interest share a positive and negative relationship, respectively, with the current profit, so higher volume and lower open interest futures contract will give better contrarian profit. Further, in emerging market, index futures provide opportunity for excess risk adjusted return due to inefficiency characterized by higher persistence of return and volatility. In their comparative study of the performances of passive and active trading strategy on Taiwan stock index futures, Chiang et al. (2012) found that active index futures trading strategy outperform the passive, i.e., buy and hold strategy.

(c) Sangram Keshari Jena, Ashutosh Dash, 2016.

Sangram Keshari Jena, Ph.D., MBA, M.Com., Associate Professor, Department of Finance, ICFAI Business School (IBS), Hyderabad, India. Ashutosh Dash, Ph.D., MBA, M.Com., MPhil, Associate Professor, Finance, Management Development Institute (MDI), India.
On part of the exchange, the objective of designing optimal contract size is to enhance the accessibility, attractiveness and liquidity of the futures contract, simultaneously achieving the two most important economic objectives of price discovery and risk management (Sibler, 1981). That's why redesigning the futures contract is taken as the last resort to attract the attention to unsuccessful contract wherever, diminishing in trading demand is observed (Bollen, Smith and Whaley, 2003). Apart from this, lower transaction cost and leverage attracts large number of traders to futures market making faster dissemination of information in futures market, thereby contributing towards price discovery function (Zhou et al., 2014). Also futures market helps players in managing the risk they are exposed to in the spot market (Darrat \& Rahaman, 1995, Pericli \& Koutmos, 1997; Darrat et al., 2002).

The study on redesigning of the contract size by Bjursell et al. (2010) found that reduction in size of the contract leads to increase in trading activities in terms of higher adjusted volume and open interest and also higher volatility due to increase in trading frequency. Further, greater liquidity in terms of lower spread and higher trading volume is documented following the reduction in contract size (Karagozoglu and Martell, 1999). Also, the study by Huang and Stoll (1998) predicted an increase in liquidity and smooth in price fluctuation following the decrease in contract size due to more participation of small investors who are so far restrained from the futures markets due to capital constraint because of higher contract value. However, Karagozoglu et al. (2003), in their study on the impact on price volatility of the reduction in contract size of S\&P 500 trading in Chicago Mercantile Exchange (CME), reported no significant impact. Nevertheless, their result might have been confounded by the de-facto reduction in 
contract size which refers to the introduction of Emini S\&P 500 futures contract on CME in September 1997 during the period of the study.

The literature on the redenomination of contract size mainly concentrated on the impact on liquidity and volatility. In this paper, the study is extended further to find out the impact of redesigning of the contract size on the twin economic functions of futures market, i.e., price discovery and risk management. Specifically the impact of reduction in contract size is studied on informed trading and hedged based trading in Nifty futures through the dynamics of return volatility and trading activity proxied by trading volume and open interest.

The National Stock Exchange of India (NSE) is the perfect ground to study this dynamics. The size of the Nifty index futures contract had been reduced two times during the sample period of the study from 200 to 100 on April 1, 2005 and further to 50 units on February 7, 2007, since it started trading in NSE from June 2001. The underlying Nifty index, consisting of 50 stocks, is the Bellwether index representing the 22 sectors of the economy and $63 \%$ of the market capitalization of the National Stock Exchange of India, giving compounded annual growth rate of $13.13 \%$ from 2000-2001 to 2009-2010. It is the third largest exchange by number of stock index future contract traded in 2009 after CME group and Eurex ${ }^{1}$.

In Figure 1, in terms of no of contracts traded, the Nifty index futures stands out as the second largest contract trading in National Stock Exchange of India (NSE) only after all the stock futures taken together, apparently showing a steady growth in the trading activity in Nifty futures. Also, it is clearly evident from the descriptive statistics presented in
Table 1 for the three different sub-periods of the study in which each period represents a particular contract size following the change, there is an increase in trading activity such as volume and open interest following the reduction in contract size from a multiple of 200 to 100 and, finally, to 50 . The volume and open interest represent total turnover of Nifty futures in lakhs and number of futures contracts outstanding at the end of the day's closing, respectively. When contract size is reduced from 200 to 50 units, average volume went up from 104403.2 lakhs per day to 1277367 lakhs and open interest from 3629920 to 29714684 contracts. Also, conditional volatility has been increased during the same period from 0.000253 to 0.000605 . These market episodes indicate a possible well-built interrelationship among the sign and scale of price movements, volatility of prices and the trading volume as shown in many previous studies (Gallant et al., 1992). How does the change in contract size impact this dynamics of Nifty futures volatility and its trading activity variables such as volume and open interest? Are there more informational trading or hedgebased trading happening due to this change and leading to the growth in turnover and volatility, as observed in Nifty futures in the Figure 1 and Table 1. The study tried to go deep into trading activity and return volatility dynamics of Nifty index futures following the two consecutive reductions in the contract size.

The rest of the paper is organized as follows. Section 1 briefly reviews the relevant literature and hypotheses development. Data and methodology are described in section 2. Section 3 covers the empirical analysis and final section concludes the study.

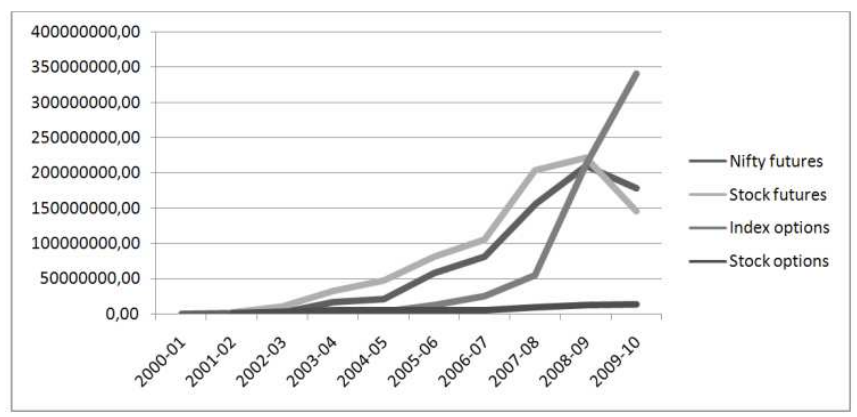

Fig. 1. Product wise no of contracts traded in NSE futures and options segment from June 2000 to September 2009

\section{Literature}

Besides fundamental factors, optimal size of the futures contract impacts the relationship dynamics amongst price volatility, volume and open interest, as one of the important determinants of the trading

\footnotetext{
1 Indian Security Market - A Review, Volume XIII 2010, www.nseinda.com.
}

by speculators (informed and noise traders) and hedgers (Silber, 1981; Watnabe, 2001). Further, there is existence of informational relationship between volatility and both volume and open interest (Brooks, 1998). In this section, two hypotheses are formulated to address the objective of the study. The objective is to find out the impact of change in contract size on the informed trading and hedgebased trading (liquidity trading) which 
leads to price discovery and risk management, respectively, in Nifty index futures. The small contract size is expected to lead to better informed trading and more hedging activities? Otherwise, it may lead to noise brought about by speculators which will destroy the whole purpose of index future. Due to reduction in lot size more small traders who are uninformed are interested to enter the market, creating more price volatility which is opposite to the price discovery function of the futures contract (Bjursell et al., 2010).

The informational dynamics in financial market, in general, and futures market, in particular, depends on the relationship between trading volume and return volatility. Mixture Distribution Hypothesis (MDH) advocated by Clark (1973) regarding theory of information in financial market states that the relationship between volatility and volume is positive and contemporaneous which depends on the rate of arrival of information into the market. Sequential Information Arrival Hypothesis (SIAH) by Copeland (1976) maintains that the relationship between volume and volatility is causal, because information arrives sequentially into the market. Most of the studies across the futures market found a positive relationship between trading volumes and return volatility (Clark, 1973; Cornell, 1981; Tauchen and Pitts, 1983; Grammatikos and Sunders, 1986)).

Concerning stock index futures positive impact of daily trading volume on volatility is reported in S\&P futures contract (Kawaller et al., 1987; Board and Sutcliffe, 1990; Kutan and Aksoy, 2003), and significant lead lag relationship is reported by Mougoue and Aggarwal (2011). The objective is to see the relationship dynamics between return volatility and trading volume following the reduction in the size of the contract. A stronger relationship is expected, as small contract size in combination with other inbuilt features of leverage, lower transaction cost of futures contract would attract informed traders, subsequently, contributing towards informational trading in the Nifty futures contract.

Further, futures market is more reactive to information in comparison to spot market because of leverage and lower transaction cost. So, the resultant trading activities create volatility in the futures market when new information arrives. Thus, in derivative market, the magnitude of volatility as a measure of information flow (Ross, 1976), is related to the trading activities. This view is complimented by Fung and Patterson (1999) who state that volatility is greater during the trading hour than the non-trading hour and also the findings of French and Roll (1986) who state that more information is released during the trading hour than the nontrading hour.
Thus, when new information arrives into the market, both volatility and trading volume would impact each other. That's why causality from volume to volatility and vice versa establishes informational trading leading to better price discovery. So, our null hypothesis (1) is that there is no price discovery in Nifty futures following the change in the size of the contract.

Besides trading volume, open interest in futures market is an additional measure of trading activity generated by large hedges (Bessembinder and Seguin, 1993). In their study, in eight physical and financial futures markets, after dividing trading volume and open interest into expected and unexpected parts, strong positive contemporaneous relationship between volume and volatility is reported. But volatility is found to be negatively related to both expected and unexpected open interest. That means, as a proxy for hedging activity and market depth, increase in open interest as of the close of the day (Bessembinder and Seguin, 1993; Kyle, 1985) alleviates volatility. As a result, open interest reflects the non-informed or liquidity trading and willingness of the traders to risk capital in futures market. Similar negative relationship is reported in Nikkei 225 stock index futures between volatility and open interest (Watanabe, 2001). Chang et al. (2000) found that increase in spot index volatility leads to increase in open interest of S\&P 500 futures contract. It's a reflection of higher demand for futures contract by the traders for hedging in response to higher level of uncertainty in spot market. Thus, increasing use of futures contract is triggered by greater volatility in futures market (which is a reflection of future expected volatility in spot and cash market). That's why, with smaller contract size, hedgers can fine tune their hedge ratio which might not have been so smooth in larger lot size. Thus, stronger negative led lag relation from open interest to volatility following the changes in contract size would be an indication of more hedging or risk management activities in Nifty index futures. Norden (2006), in the context of split of OMX index futures contract in the Swedish exchange for options and futures, found that futures split led to lowering of basis risk and improved hedging efficiency. Thus, open interest as a proxy for hedging activity caused by volatility is expected to increase following the reduction in contract size. This, result support the hedged based trading in index futures. Thus, our null hypothesis (2) is that there is no impact on hedgebased trading following the change in the size of the Nifty index futures.

\section{Data and methodlogy}

2.1. Data. To address the hypothesis postulated in the previous section, daily closing prices, rupee 
trading volume (turnover) and open interest of near month Nifty futures contract are taken from 6 June 2000 through 29 September 2009. In total, we have 2,323 daily observations of closing price, trading volume and open interest obtained from the official website of National Stock Exchange of India $(\mathrm{NSE})^{2}$. CNX Nifty is a Bellwether index of the NSE representing 50 stocks across 22 sectors, 52\% of the traded volume and $63 \%$ of market capitalization of the NSE. NSE, in order to attract more market participants to the Nifty futures contracts, reduced the lot size from 200 to 100 and then 100 to 50 units w.e.f April 1, 2005 and February 7, 2007, respectively, two times in the sample period. Accordingly, data have been divided into three subsamples considering the no of split in contract size of the index futures during the period of the study. The first subsample period spans from $06 / 12 / 2000$ to $03 / 31 / 2005$ with the lot size of 200 multiples of Nifty index. The second sample period starts from 04/01/2005 to 02/06/2007 with 100 multiples of the Nifty index futures and, finally, lot size of 50 from 02/07/2007 to 09/24/2009.

Following Campbell et al. (1993) and Fung \& Patterson (1999), for the study, we have formed stationary time series of trading volume and open interest by incorporating the following procedure through Eq. (1) using 100 days backward moving average. The resultant time series captures the change in the long run movement in trading volume and open interest.

$$
V_{t}=\frac{V T_{t}}{1 / 100 \sum_{i=1}^{100} V T_{t-i}},
$$

where $V T_{t}$ is the log of trading volume at time $t$ and, for open interest, it represents the log open interest at time $t$. In the denominator, 100 days moving average starting from $t-1$ to $t-100$ of volume and open interest is taken. The transformation through Eq. (1) helps to mitigate the mechanical link between volume and open interest in the actual trading and enables to interpret the information structure relating to volume, open interest and price movements through VAR analysis. $V_{t}$ is the average trading volume (VOL_100) and open interest (OI_100) for time $t$ which is taken for further study through equation (5). The daily return series $\left(r_{t}\right)$ is calculated as the first difference of the logarithms of daily closing prices of near month Nifty index futures contracts which is taken for calculation of daily conditional volatility through equation (2), (3) and (4) for further study.
The unconditional daily mean return of the Nifty index futures is $0.000531 \%$, with a standard deviation of $0.018 \%$. The return series is fat-tailed, as reported by excess kurtosis of 11.53 and negatively skewed, since the reported skewness is -0.48 . The Jarque-Bera test rejects the null hypothesis of normality. The evidence of the existence of excess kurtosis is due to a possible time varying variance, as documented by Akigary et al. (1991) and Fujihara and Mougoue (1997). Further, the presence of heteroscedasticity in the index return is significant at lag 10 as per the ARCH LM test (Engle, 1982) (available on request). Therefore, conditional volatility of Nifty index futures is taken for the study of the dynamic interrelationship among volatility, volume and open interest in near month future contract. The ARCH class of model, i.e., GARCH $(1,1)$ being parsimonious is used to estimate the conditional volatility of return.

Conditional volatility following $\operatorname{GARCH}(1,1)$ model proposed by Bollerslev (1986) is estimated from Eq. (2) through (4). In GARCH $(1,1)$ model, the conditional variance $h_{t}$ in Eq (4) is a function of a long run average variance rate $(\omega)$, lagged squared error term represented by news $\left(\varepsilon_{t-1}^{2}\right)$ and its own lag $\left(h_{t-1}\right)$.

$$
\begin{aligned}
& r_{t}=c+b r_{t-1}+\varepsilon_{t}, \\
& \varepsilon_{t} / I_{t-1} \sim N\left(0, h_{t}\right), \\
& h_{t}=\omega+\alpha \varepsilon_{t-1}^{2}+\beta h_{t-1} .
\end{aligned}
$$

Augmented Dicky-Fuller (ADF, 1979) test is used to test the stationarity in the return volatility series $\left(h_{t}\right)$, volume and open interest. The ADF test results ${ }^{3}$ strongly reject the null hypothesis that the Nifty index futures return volatility series and trading volume and open interest series are non-stationary. Therefore, three resultant time series variables, i.e., conditional volatility $h_{t}$ (GARCH01), volume (VOL_100) and open interest (OI_100) are taken for further analysis in this study in equation (5) through (8).

2.2. Methodology. To investigate the interrelationship between Nifty index futures volatility, volume and open interest in the near month contract, Vector Autoregressive (VAR) model is used in the study. It is the generalized multivariate form of univariate autoregressive model, carrying the most valuable feature of estimating the dynamic interrelationship between variables without any choice of having dependent and independent variables. Further, Granger causality is conducted on the estimates of VAR model to determine the causal relationship among Nifty index futures volatility and trading activity variables such as volume and open interest. Causal

\footnotetext{
${ }^{3}$ Results are available on request.
} 
relationship does not imply any cause and effect relationship, rather it is based on "predictability or forecastability" (Granger, 1969). The nature of forecastability depends on the strength of the association among the system variables. So, the variance decomposition is done to find out magnitude of the dynamic relationship and impulse response function to trace out the direction and speed of the dynamic effect among the volatility, volume and open interest of Nifty index futures. Variance decomposition helps in finding the variation in each variable in the system that is contributed by its own shock, and shocks produced from other variables. The impulse response function provides the direction and time profile of the effects of own shocks, and shocks from other variables in the system on the future behavior of the variables.

The reduced form of the VAR model used in this study is presented as follows through equation (5) to estimate the interrelationships among daily volatility, trading volume and open interest of Nifty index futures:

$Y_{t}=c+\sum_{k=1}^{L} a_{k} Y_{t-k}+e_{t}$,

where $Y_{t}$ is a $3 \times 1$ column vector of volatility (GARCH01), adjusted trading volume (VOL_100) and adjusted open interest (OI_100) at time $t . \overline{\mathrm{c}}$ and $a_{k}$ are $3 \times 1$ and $3 \times 3$ matrices of coefficients, $L$ is the lag length, $e_{t}$ is the $3 \times 1$ column vector of error terms. The direct effect of $i_{t h}$ variable upon $j_{t h}$ variable after $\mathrm{k}$ periods is measured by the $(i, j)$ component of $\alpha_{k}$. Specifically, the $i_{t h}$ component of $e_{t}$ is the innovation of the $i_{t h}$ variable that cannot be predicted from the other variables in the system.

The VAR is rewritten in the form of following individual equations through equation (6), (7) and (8) to test the joint hypothesis that "Does volume (VOL_100) granger cause volatility (GARCH01) ceteris-paribus"? Likewise, for other joint hypothesis for causality from OI 100 to VOL 100 , GARCH01 to OI_100, OI_100 to GARCH01, and VOL_100 to OI_100. As all the variables in the VAR system are stationary, their joint hypothesis can be tested using Fstatistics.

$\mathrm{H} 1$, the first null hypotheses postulates that there is no informed trading following the change in contract size. That means there is no granger causality between volatility and trading volume and vice versa following the reduction in lot size.

So, $\beta_{21}=\beta_{22}=\ldots \quad=\beta_{2 L=0}$ in equation (6) and in equation (7) $\gamma_{11}=\gamma_{12} \ldots \ldots$

A rejection of the joint hypotheses of zero value for lagged $\beta_{2 k}$ and $\gamma_{1 k}$ supports the information based trading in Nifty futures.
$\mathrm{H} 2$, our second null hypothesis postulates that change in contract size does not impact the hedging activities. That means there is no Granger causality from volatility to open interest. So, in equation (8):

$\delta_{11}=\delta_{12}=$

A rejection of the joint hypotheses of zero value of the lagged $\delta_{1 k}$ supports the hedgebased trading in Nifty futures.

$$
\begin{aligned}
& \text { GARCH01 }=c_{10}+\beta_{1 k} \sum_{k=1}^{L} \text { GARCH01 } 1_{t-k}+ \\
& +\beta_{2 k} \sum_{k=1}^{L} V O L_{t-k}+e_{1 t}, \\
& V O L_{t}=c_{20}+\gamma_{1 k} \sum_{k=1}^{L} G A R C H 01_{t-k}+\gamma_{2 k} \sum_{k=1}^{L} V O L_{t-k}+ \\
& +\gamma_{3 k} \sum_{k=1}^{L} O I_{t-k}+e_{2 t} \\
& O I_{t}=c_{30}+\delta_{1 k} \sum_{k=1}^{L} G A R C H 01_{t-k}+\delta_{2 k} \sum_{k=1}^{L} V O L_{t-k}+ \\
& +\delta_{2 k} \sum_{k=1}^{L} V O L_{t-k}+\delta_{3 k} \sum_{k=1}^{L} O I_{t-k}+e_{3 t .}
\end{aligned}
$$

In an effort to provide further insight into the dynamic interrelationship among the variables, VAR model is represented as moving average model of innovations of the system variables through equation (9):

$Y_{t}=\sum_{k=1}^{\infty} A_{k} e_{t-k}$.

The $\mathrm{m}$ step ahead forecast error of $Y_{t}$ can be computed from the moving average model of VAR in Eq. (9). Breaking up of the variation of the forecast error of the variable $Y_{t}$, variance decomposition explains the unexpected change in the variation of each variable produced by shocks from other system variables.

Impulse response function traces out the responsiveness of the dependent variable in the system to the shocks/innovations or impulses of own and other variables in the system.

Eq. (9) is transformed and presented through equation (10) and (11) to remove the contemporaneous correlation across equation by the process of orthogonalization. Though the innovations $e_{t}$ is serially uncorrelated, but, across equations in the VAR system, they might be correlated:

$Y_{t}=\sum_{k=1}^{\infty} A_{k} V u_{t-k}$.

Such that, 


$$
Y_{t}=\sum_{k=1}^{\infty} C_{k} u_{t-k}
$$

$V$ is a lower triangular matrix.

Now, $u_{t}$ is serially and contemporaneously uncorrelated innovation which is orthogonalized innovation from $e=V_{u}$ with an independent covariance matrix.

\section{Empirical analysis}

In this section, the results of VAR analysis are reported, the Granger causality through Table 2, the variance decomposition in Table 3 and the impulse response function through Figures 2, 3 and 4.

3.1. Individual behavior of volume, volatility and open interest. The volatility has been increasing over the period (Table 1) and also became more persistent following the change in contract size (last column of Figure 4) signifying more information flow through more trading activities. It's evident from descriptive statistics presented in Table 1 that there is an increase in trading activities represented by volume and open interest over the changed period. The response of volatility to its own shock became highly persistent, i.e., the impact does not die out (last column of Figure 4) and also it got impacted by volume shock at lag 1 following the change in contract size to 50 multiple (Panel C, Table 3). But there is a change in persistence level of volume and open interest from high to low over the period following the changes in the contract size. In case of open interest, the impact dies out within 11 days and, for volume, within 4 days of the shocks.

3.2. Volume and volatility. From the reported result of Granger causality in Table 2, is evident that the coefficients $\beta_{21}, \beta_{22,--} \beta_{2 L}$ in Panel $\mathrm{C}$ and $\gamma_{11}, \gamma_{12---}, \gamma_{1 L}$ in Panel $\mathrm{B}$ become significant under the contract size of 50 multiple in contrast to the previous two period sat $5 \%$ level of significance, thereby rejecting the null hypothesis 1 . Thus, the relationship dynamics between the volume and volatility over the period of reduction of contract size changed from no causality to significant feedback relationship. Now, volume is Granger caused by volatility and vice versa. Thus, given the information on previous day's volume, volatility can be predicted, and vice versa, the dynamics is associated with the sequential arrival of information to Nifty futures market. It confirms the findings of Chen and Daigler (2008) who found that information reaches the different group of traders at different times. Further, the speed of adjustment of information into the prices also becomes stronger, as evident (in the Figure 3) from the impulse response of volatility to one unit shock to volume which dies out in 5 days. It's in contrast to the results relating to the previous two periods where high volatility persistence is apparent. Thus, information - based trading is strengthened following the reduction in lot size, subsequently, contributing to the price discovery. Moreover, the mean value of volatility and volume rose from .000253 to .000605 and 104403.2 to 1277367 , respectively (see Table 1) following the reduction from 200 to 50 multiple, and are driven by information, as the first moment of volatility process is driven by information and the second moment of volatility, i.e., excess volatility is attributed to different interpretation of information and reactions of traders to information (Shalen, 1993). Its supplemented by the $4 \%$ decomposed variance of volatility, which caused the variation in the volume in Panel C, Table 3.

However, partly this may be attributed to noise trading by uninformed investors which normally trade on changes on volume and price happened in the market due to informed trading (Delong, Shelifer, Summers and Walmann, 1990). It causes increase in the second moment of volatility called transitory volatility which is not permanent like fundamental volatility caused by informed trading (Shalen, 1993; Chen and Daigler, 2008). Since around $4 \%$ of the forecasted error of volatility is explained by the shocks, i.e., unexpected volume, noise trading cannot be completely ruled out in Nifty index futures following the split of the contract into smaller lot size.

3.3. Open interest and volatility. Inconsistency in causality from volatility to open interest is observed in Table 2 over the changed period of the contract size. The coefficients $\delta_{11}, \delta_{12}, \ldots, \delta_{1 L}$ in Panel Aare statistically insignificant during the period of contract size of 200 and 50, though it is significant in the period of 100 contract size. Thus, the nonrejection of null hypothesis 2 indicates that change in the size of the contract from 200 to, finally, 50 does not improve the hedging activities in Nifty index futures. It is also evident in the impulse response function of open interest to one unit of shock to volatility in column two, Figure 2 which is almost zero. However, open interest Granger causes volatility only when size of the contract is changed to 50 , as the coefficient $\beta_{3 k}$ is significant at $1 \%$ level significance in equation (7) and panel $\mathrm{C}$ of Table 2. Also, the impulse response function of volatility to shocks in open interest is positive and very persistent in column one, Figure 3. That means volatility in Nifty index futures is caused by uninformed and liquidity trading; open interest being a proxy for uninformed and liquidity trading (Bessembinder and Seguin, 1996). It supports the findings of Delong et al. (1990a) and (1990b) that, following the cutback in the contract size, uninformed traders are prevalent in the index futures market. 
3.4. Volume and open interest. Both volume and open interest are complementary to each other, as is evidenced from feedback relationships from the significant Granger causality runs from volume and open interest and vice versa over the period (Panel A and B, Table 2). Thus, both open interest and volume are endogenous which is in contrast to the findings of Fung \& Patterson (1999). It is also supplemented by variance decomposition of volume in which around $3 \%$ is explained by the shocks of open interest. However, our results support Bessembinder et. al. (1996), as open interest is a determinant of volume. Further, from impulse response functions in column two, Figure 2, it is observed that the time profile and direction of the response of open interest to volume shocks is changed from positive to negative and it becomes less persistence.

\section{Conclusions}

Through the dynamics of the relationship between volatility, volume and open interest, the study examined the impact of the change in size of the Nifty index futures contract on the two most important functions of futures market, i.e., price discovery and risk management, besides satisfying all other stakeholders of the futures market. The relationship dynamics between volatility and volume, volatility and open interest and volume and open interest has been changed over the period with the change in the size of the futures contract from 200 to 100 and, subsequently, to 50. The stronger causality between volume and volatility establishes the informational trading in Nifty futures contract. However, no evidence hedgebased trading is observed following reduction in the size of the contract. But, non-informational and liquidity trading is manifested in the Nifty futures market due to the smaller size of the futures contract. Nonetheless, no change in causality from volume to open interest had been observed over the period, but its direction and time profile changed in the smaller lot size. Though it is a regulatory issue, changing the size of the futures contract impacts the informational and not the hedging activities of index futures contract. So, stock exchanges should consider the appropriate lot size before going for introducing new futures contract. This study is undertaken on daily data for index futures. Further research could be undertaken on intraday data on both index and stock futures to investigate price discovery and hedging effectiveness in futures market following the change in contract size.

\section{References}

1. Akgiray, V., Booth G.C., Hatem, J.J. and Mustafa, C. (1991). Conditional dependence in precious metal prices, The Financial Review, 26, pp. 367-386.

2. Darrat, A.F., Rahman, S. and Zhong, M. (2002). On the Role of Futures Trading in Spot Market Fluctuations: Perpetrator of Volatility or Victim of Regret? Journal of Futures Market, 25(3), pp. 431-444.

3. Bessembinder, H., Chan, K., Seguin, P.J. (1993). Price volatility, trading volume and market depth: Evidence from futures market, Journal of Financial and Quantitative Analysis, 28, pp. 21-40.

4. Bessembinder, H., Chan, K., Seguin, P.J. (1996). An empirical examination of information, differences of opinion, and trading activity, Journal of Financial Economics, 40, pp. 105-134.

5. Bjursell, J., Frino, A., Tse, Y. and Wang, George H.K. (2010). Volatility and trading activity following changes in the size of futures contract, Journal of Empirical Finance, 17, pp. 967-980.

6. Board J.L., Sutcliffe C.M.S. (1990). Information, volatility, volume and maturity: an investigation of stock index futures, Review Futures Markets, 9(3), pp. 191-210.

7. Bollen Nicolas, P.B., Smith, T. and Whaley, R.E. (2003). Optimal contract design: for whom? Journal of Futures Markets, 23(8), pp. 719-750.

8. Bollerslev, T. (1986). Generalized autoregressive conditional heteroskedasticity, Journal of Econometrics, 33(1), pp. 307-327.

9. Brooks, C. (1998). Predicting stock index volatility: can market volume help? Journal of Forecasting, 17(1), pp. 59-80.

10. Campbell, J.Y., Grossman, S.J., Wang, J. (1993). Trading volume and serial correlation in stock returns, Quarterly Journal of Economics, 108, pp. 905-939.

11. Chang, E., Chou R.Y. and Nellling E.F. (2000). Market volatility and the demand for hedging in stock index futures, Journal of Futures Market, 20, pp. 105-125.

12. Chen, Z. and Daigler, R.T. (2008). An examination of the complementary volume-volatility information theories, Journal of Futures Market, 28(10), pp. 963-992.

13. Chiang, Y.C., Ke, M.C., Liao, T.L. and Wang, C.D. (2012). Are technical trading strategies still profitable? Evidence from the Taiwan Stock Index Futures Market, Applied Financial Economics, 22, pp. 955-965.

14. Clark, P.K. (1973). A subordinated stochastic process model with finite variance for speculative prices, Econometrica, 4, pp. 135-155.

15. Copeland, T.E. (1976). A model of asset trading under the assumption of sequential information arrival, Journal of Finance, 31, pp. 1149-1168.

16. Cornell, B. (1981). The relationship between volume and price variability in futures market, Journal Futures Market, 1, pp. 303-316. 
17. Darrat, A.F. and Rahman. S. (1995). Has futures trading activity caused stock price volatility? Journal of Futures Market, 15(5), pp. 537-557.

18. DeLong, J.B., Shleifer, A., Summers, L.H. \& Waldmann, R.J. (1990a). Noise trader risk in financial markets, Journal of Political Economy, 98, pp. 703-738.

19. DeLong, J.B., Shleifer, A., Summers, L.H. \& Waldmann, R.J. (1990b). Positive feedback investment strategies and destabilized rational speculation, The Journal of Finance, 45, pp. 379-395.

20. Dickey, D.A., Fuller, W.A. (1979). Distribution of the Estimators for Autoregressive Time Series with a Unit Root, Journal of the American Statistical Association, 74, pp. 427-431.

21. Engle, R.F. (1982). Autoregressive conditional heteroskedasticity with estimates of the variance of U.K. inflation, Econometrica, 50, pp. 987-1008.

22. French, K. and Roll, R. (1986). Stock return variances: the arrival of information and reaction of traders, Journal of Financial Economics, 17(1), pp. 5-26.

23. Fujihara, R.A., Mougoue, M. (1997). Linear dependence, nonlinear dependence and petroleum futures market efficiency, Journal of Futures Markets, 17, pp. 75-99.

24. Fung, H.G. and Patterson, G.A. (1999). The dynamic relationship of volatility, volume and market depth in currency futures market, Journal of International Markets, Institutions and Money, 9, pp. 33-59.

25. Gallant, A.R., Rossi, P.E., Tauchen, G. (1992). Stock prices and volume, Review of Financial Studies, 5(2), pp. 199-242.

26. Grammatikos, T., Saunders, A. (1986). Futures' price variability: a test of maturity and volume effect, Journal of Business, 59, pp. 309-330.

27. Granger, C.W.J. (1969). Investigating causal relations by econometric models and cross-spectral methods, Econometrica, 37, pp. 424-438.

28. Huang, R.D., Stoll, H.R. (1998). Is it time to split the S\&P 500 futures contract? Financial Analyst Jobs, 53, pp. 23-35.

29. Karagozoglu, A.K., Martell, T. (1999). Changing the size of a futures contract: liquidity and microstructure effects, Financial Review, 34, pp. 75-94.

30. Karagozoglu, A.K., Martell, T., Wang, G.H.K. (2003). The split of the S\&P 500 futures contract: effects on liquidity and market dynamics, Review of Quantitative Finance and Accounting, 21, pp. 323-348.

31. Kawaller, I.G., Koch, P.D., Koch, T.W. (1987). The temporal price relationship between S\&P 500 Futures and the S\&P Index, Journal of Finance, 42, pp. 1309-1329.

32. Kutan, A.M., Aksoy, T. (2003). Public information arrival and the Fisher effect in emerging market, Journal of Financial Services Research, 23(3).

33. Kyle, A.S. (1985). Continuous auctions and insider trading, Econometrica, 53, pp. 1315-1335.

34. Mougoue, M., Aggarwal, R. (2011). Trading volume and exchange rate volatility; evidence for the sequential arrival of information hypothesis, The Journal of Banking and Finance, 35, pp. 2690-2703.

35. Norden, L. (2006). Does an index futures split enhance trading activity and hedging effectiveness of the futures contract? Journal of Futures Markets, 26(12), pp. 1169-1194.

36. Pericli, A., Koutmos, G. (1997). Index futures and options and stock market volatility, Journal of Futures Market, 17 (8), pp. 957-974.

37. Ross, S.A. (1976). Options and efficiency, Quarterly Journal of Economics, 90, pp. 75-89, doi: 10.2307/1886087.

38. Shalen, C.T. (1993). Volume, volatility, and the dispersion of beliefs, Review of Financial Studies, 6, pp. 405-434.

39. Silber, W.L. (1981). Innovation, competition, and new contract design in futures market, Journal of Futures Market, 1, pp. 123-155.

40. Tauchen, G.E., Pitts, M. (1983). The price variability-volume relationship on speculative markets, Econometrica, 51, pp. 485-505.

41. Wang, C. and Yu, Min. (2004). Trading activity and price reversals in futures market, Journal of Banking and Finance, 28, pp. 1337-1361.

42. Watanabe, T. (2001). Price volatility, trading volume and market depth, evidence from Japanese stock index futures market, Applied Financial Economics, 11(6), pp. 651-658.

43. Zhou, Z., Dong, H. and Wang, S. (2014). Intraday volatility slipovers between index futures and spot market: Evidence from China, Procedia Computer Science, 31, pp. 721-730. 


\section{○ै Appendix}

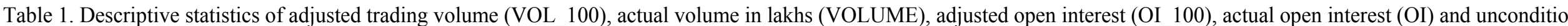

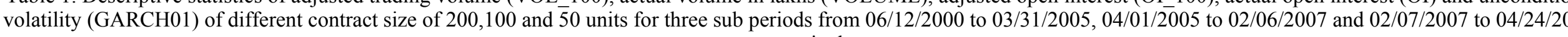
respectively

\begin{tabular}{|c|c|c|c|c|c|c|c|c|c|c|c|c|c|c|c|}
\hline & \multicolumn{5}{|c|}{ Contact size 200} & \multicolumn{5}{|c|}{ Contract size 100} & \multicolumn{5}{|c|}{ Contract size 50} \\
\hline & GARCH01 & Ol_100 & $\mathrm{Ol}$ & VOL_100 & VOLUME & GARCH01 & Ol_100 & Ol & VOL_100 & VOLUME & GARCH01 & Ol_100 & Ol & VOL_100 & VOLUME \\
\hline Mean & 0.000253 & 1.017575 & 3629920 & 1.035022 & 104403.2 & 0.000267 & 1.004925 & 22075967 & 1.007433 & 671516.7 & 0.000605 & 0.999544 & 29714684 & 1.003027 & 1277367 \\
\hline Median & 0,000168 & 1.016775 & 1893000 & 1.026211 & 16587.18 & 0.000165 & 1.009936 & 22981500 & 1.005801 & 663118.5 & 0.000461 & 1.003187 & 30927250 & 1.002118 & 1244392 \\
\hline Maximum & 0,006006 & 1.134429 & 17198400 & 720437.5 & 720437.5 & 0.002151 & 1.035065 & 37084200 & 1.086502 & 1863217 & 0.004689 & 1.027973 & 44400050 & 1.078559 & 3091293 \\
\hline Minimum & $6.19 \mathrm{E}-05$ & 0.888918 & 4000 & 0.763283 & 51.87 & $6.90 \mathrm{E}-05$ & 0.9321 & 5534900 & 0.849056 & 101241.3 & $7.54 \mathrm{E}-05$ & 0.923456 & 7272150 & 0.851591 & 131141.5 \\
\hline Std.dev. & 0,000395 & 0.033931 & 4006149 & 0.065963 & 144365.5 & 0.000309 & 0.01921 & 5723029 & 0.028013 & 312250.1 & 0.000593 & 0.01786 & 7467872 & 0.023086 & 399724.7 \\
\hline Skewness & 9.051996 & 0.490164 & 1.136981 & 0.686921 & 1.380761 & 3.440982 & -1.60552 & -0.680226 & -0.393311 & 0.732384 & 3.175952 & -1.44672 & -0.6968 & -0.367287 & 0.84816 \\
\hline Kurtosis & 107.4346 & 4.624241 & 3.14451 & 4.896333 & 4.155072 & 15.68247 & 5.610481 & 3.683959 & 6.1528 & 3.86036 & 16.35718 & 5.397237 & 3.180091 & 7.068493 & 4.869162 \\
\hline Jarkue-Bera & 565462.3 & 166.4632 & 261.5364 & 253.6128 & 451.3695 & 4025.327 & 331.0909 & 44.82682 & 204.1391 & 55.79149 & 5924.773 & 382.3825 & 53.44756 & 462.9147 & 172.5553 \\
\hline Probability & 0 & 0 & 0 & 0 & 0 & 0 & 0 & 0 & 0 & 0 & 0 & 0 & 0 & 0 & 0 \\
\hline Sum & 0.30524 & 1129.508 & $4.39 e+09$ & 1148.875 & $1.26 \mathrm{E}+08$ & 0.123984 & 466.2851 & $1.02 \mathrm{E}+10$ & 467.449 & $3.12 \mathrm{E}+08$ & 0.393376 & 649.7037 & $1.93 \mathrm{E}+10$ & 651.9674 & $8.30 \mathrm{E}+08$ \\
\hline Sum. sq. dev. & 0.000188 & 1.276774 & $1.94 \mathrm{E}+16$ & 4.825373 & $2.52 E+13$ & $4.42 \mathrm{E}-05$ & 0.17804 & $1.52 \mathrm{E}+16$ & 0.363334 & $4.51 \mathrm{E}+13$ & 0.000229 & 0.207019 & $3.62 \mathrm{E}+16$ & 0.345893 & $1.04 \mathrm{E}+14$ \\
\hline Observations & 1208 & 1110 & 1209 & 1110 & 1209 & 464 & 464 & 464 & 464 & 464 & 650 & 650 & 650 & 650 & 650 \\
\hline
\end{tabular}

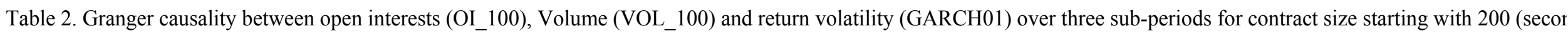
column), followed by 100 (third column), 50 (fourth) and, finally, for the full period (fifth column)

\begin{tabular}{|c|c|c|c|c|c|c|c|c|c|c|c|c|}
\hline \multirow{2}{*}{$\begin{array}{c}\text { Panel C } \\
\text { Dependent variable: OI }\end{array}$} & \multicolumn{3}{|c|}{ Contract size 200} & \multicolumn{3}{|c|}{ Contract size 100} & \multicolumn{3}{|c|}{ Contract size 50} & \multicolumn{3}{|c|}{ Full period } \\
\hline & Chi-sq & $\mathrm{df}$ & Prob. & Chi.sq & $d f$ & Prob. & Chi.sq & $\mathrm{df}$ & Prob. & Chi.sq & $\mathrm{df}$ & Prob. \\
\hline VOL & 13.13644 & 2 & $0.0014^{\star \star \star}$ & 4.73782 & 1 & $0.0295^{\star *}$ & 2.690562 & 1 & $0.1009^{*}$ & 23.82611 & 2 & $0.000^{* \star \star}$ \\
\hline GARCHO01 & 2.931166 & 2 & 0.2309 & 3.754203 & 1 & $0.0527^{\star *}$ & 0.581999 & 1 & 0.4455 & 6.635211 & 2 & $0.0362^{* \star}$ \\
\hline \multicolumn{13}{|l|}{ Panel B } \\
\hline $\begin{array}{l}\text { Dependent variable: } \\
\text { VOL }\end{array}$ & Chi-sq & df & Prob. & Chi-sq & df & Prob. & Chi-sq & df & Prob. & Chi-sq & df & Prob. \\
\hline $\mathrm{Ol}$ & 16.97928 & 2 & $0.0002^{\star \star \star}$ & 2.053432 & 1 & 0.1519 & 3.210704 & 1 & $0.0732^{\star}$ & 41.65201 & 2 & $0.000^{\star \star}$ \\
\hline GARCHO01 & 3.33855 & 2 & 0.1884 & 0.001742 & 1 & 0.9667 & 5.141418 & 1 & $0.0234^{* *}$ & 11.05285 & 2 & $0.004^{* \star \star}$ \\
\hline \multicolumn{13}{|l|}{ Panel C } \\
\hline $\begin{array}{l}\text { Dependent variable: } \\
\text { GARCHO01 }\end{array}$ & Chi-sq & df & Prob & Chi-sq & df & Prob. & Chi-sq & df & Prob. & Chi-sq & df & Prob. \\
\hline $\mathrm{Ol}$ & 2.939719 & 2 & 0.23 & 1.192222 & 1 & 0.2749 & 5.440987 & 1 & $0.0197^{\star \star \star}$ & 4.761144 & 2 & $0.0925^{\star}$ \\
\hline VOL & 3.563612 & 2 & 0.1683 & 30.75514 & 1 & $0.000^{\star \star \star}$ & 5.402987 & 1 & $0.0201^{* *}$ & 0.100914 & 2 & 0.9508 \\
\hline
\end{tabular}

Notes: $* * * * *$ and $*$ indicate $1 \%, 5 \%$ and $10 \%$ level significance. 
Table 3. Variance decomposition of open interest (OI_100), volume (VOL_100) and volatility (GARCH01). It explains the variance one variable caused by the shocks in another variable over three sub-periods for contract size starting with 200 (second column), followed by 100 (third column), 50 (fourth) and finally for the full period (fifth column)

\begin{tabular}{|c|c|c|c|c|c|c|c|c|c|c|c|c|}
\hline \multirow{2}{*}{$\begin{array}{l}\text { Various } \\
\text { decomp } \\
\text { osition } \\
\text { of Ol: } \\
\text { Panel A } \\
\text { Period } \\
\end{array}$} & \multicolumn{3}{|c|}{ Lot size 200} & \multicolumn{3}{|c|}{ Lot size 100} & \multicolumn{3}{|c|}{ Lot size 50} & \multicolumn{3}{|c|}{ Full Period } \\
\hline & Ol & VOL & GARCH01 & Ol & VOL & GARCH01 & Ol & VOL & GARCH01 & Ol & VOL & GARCH01 \\
\hline 1 & 100 & 0 & 0 & 100 & 0 & 0 & 100 & 0 & 0 & 100 & 0 & 0 \\
\hline 2 & 99.6081 & 0.3158 & 0.0761 & 99.4024 & 0.5612 & 0.0364 & 99.7821 & 0.2077 & 0.0102 & 99.8486 & 0.0968 & 0.546 \\
\hline 3 & 99.0725 & 0.7335 & 0.1939 & 98.6421 & 1.2409 & 0.1171 & 99.5159 & 0.4568 & 0.0273 & 99.3715 & 0.4884 & 0.1400 \\
\hline 4 & 98.4198 & 1.2475 & 0.3328 & 97.9595 & 1.8071 & 0.2334 & 99.2942 & 0.6585 & 0.0473 & 98.7760 & 0.9658 & 0.2582 \\
\hline 5 & 97.7388 & 1.7805 & 0.4807 & 97.4053 & 2.2208 & 0.3740 & 99.1347 & 0.7978 & 0.0675 & 98.1054 & 1.4940 & 0.4006 \\
\hline 10 & 94.8283 & 3.9956 & 1.1760 & 95.8534 & 3.0127 & 1.1339 & 98.8657 & 0.9918 & 0.1426 & 95.1172 & 3.5930 & 1.2897 \\
\hline 15 & 93.1896 & 5.1635 & 1.6469 & 95.0798 & 3.2131 & 1.7071 & 98.8238 & 1.0003 & 0.1759 & 93.3827 & 4.4917 & 2.1256 \\
\hline 20 & 92.4082 & 5.6860 & 1.9058 & 94.5998 & 3.3146 & 2.0856 & 98.8104 & 1.0004 & 0.1891 & 92.4977 & 4.7837 & 2.7186 \\
\hline 25 & 92.0589 & 5.9082 & 2.0329 & 94.2900 & 3.3779 & 2.3321 & 98.8053 & 1.0004 & 0.1943 & 92.0554 & 4.8650 & 3.0796 \\
\hline $\begin{array}{l}\text { Various } \\
\text { decomp } \\
\text { osition } \\
\text { of VOL: } \\
\text { Panel B }\end{array}$ & \multicolumn{3}{|c|}{ Lot size 200} & \multicolumn{3}{|c|}{ Lot size 100} & \multicolumn{3}{|c|}{ Lot size 50} & \multicolumn{3}{|c|}{ Full Period } \\
\hline Period & Ol & VOL & GARCH01 & Ol & VOL & GARCH01 & Ol & VOL & GARCH01 & Ol & VOL & GARCH01 \\
\hline 1 & 4.2595 & 95.7405 & 0.0000 & 0.2596 & 99.7404 & 0.0000 & 3.1545 & 96.8455 & 0.0000 & 3.2885 & 96.7115 & 0.0000 \\
\hline 2 & 5.2138 & 94.7054 & 0.0808 & 0.6486 & 99.3513 & 0.0000 & 4.1095 & 95.7851 & 0.1054 & 4.0097 & 95.7489 & 0.2415 \\
\hline 3 & 6.5197 & 93.2889 & 0.1914 & 0.9837 & 99.0162 & 0.0000 & 4.7900 & 94.9014 & 0.3086 & 5.5680 & 94.0733 & 0.3587 \\
\hline 4 & 7.7822 & 91.8732 & 0.3446 & 1.2057 & 98.7941 & 0.0002 & 5.2044 & 94.2368 & 0.5588 & 7.1103 & 92.3740 & 0.5156 \\
\hline 5 & 9.0099 & 90.4782 & 0.5119 & 1.3312 & 98.6681 & 0.0007 & 5.4271 & 93.7577 & 0.8152 & 8.6388 & 90.6906 & 0.6706 \\
\hline 10 & 13.6224 & 85.0988 & 1.2789 & 1.4473 & 98.5458 & 0.0069 & 5.5868 & 92.6803 & 1.7329 & 13.9708 & 84.5235 & 1.5057 \\
\hline 15 & 15.9141 & 82.3808 & 1.7051 & 1.4484 & 98.5383 & 0.0133 & 5.5664 & 92.3152 & 2.1184 & 16.0864 & 81.6798 & 2.2338 \\
\hline 20 & 16.9216 & 81.1841 & 1.8944 & 1.4484 & 98.5337 & 0.0179 & 5.5615 & 92.1698 & 2.2687 & 16.7772 & 80.4801 & 2.7427 \\
\hline 25 & 17.3473 & 80.6795 & 1.9732 & 1.4485 & 98.5307 & 0.0209 & 5.5605 & 92.1124 & 2.3272 & 16.9780 & 79.9706 & 3.0514 \\
\hline $\begin{array}{l}\text { Various } \\
\text { decomp } \\
\text { osition } \\
\text { of } \\
\text { GARCH } \\
\text { 01: } \\
\text { Panel C }\end{array}$ & \multicolumn{3}{|c|}{ Lot size 200} & \multicolumn{3}{|c|}{ Lot size 100} & \multicolumn{3}{|c|}{ Lot size 50} & \multicolumn{3}{|c|}{ Full Period } \\
\hline Period & Ol & VOL & $\begin{array}{c}\text { GARCHO } \\
1\end{array}$ & Ol & VOL & $\begin{array}{c}\text { GARCHO } \\
1\end{array}$ & Ol & VOL & $\begin{array}{c}\text { GARCHO } \\
1\end{array}$ & Ol & VOL & GARCH01 \\
\hline 1 & 0.0729 & 0.0008 & 99.9263 & 0.0129 & 0.8071 & 99.1801 & 0.1022 & 4.1677 & 95.7301 & 0.1178 & 0.2331 & 99.6491 \\
\hline 2 & 0.0584 & 0.1261 & 99.8154 & 0.0774 & 5.1862 & 94.7364 & 0.0864 & 2.9794 & 96.9342 & 0.0661 & 0.2328 & 99.7012 \\
\hline 3 & 0.0957 & 0.1637 & 99.7406 & 0.2507 & 8.9056 & 90.8438 & 0.1945 & 2.3076 & 97.4979 & 0.0584 & 0.2558 & 99.6859 \\
\hline 4 & 0.1477 & 0.1967 & 99.6555 & 0.4712 & 11.5780 & 87.9508 & 0.3536 & 1.9099 & 97.7365 & 0.0600 & 0.2837 & 99.6563 \\
\hline 5 & 0.2044 & 0.2218 & 99.5738 & 0.6998 & 13.4332 & 85.8670 & 0.5250 & 1.6624 & 97.8126 & 0.0656 & 0.3125 & 99.6220 \\
\hline 10 & 0.4891 & 0.3105 & 99.2004 & 1.5484 & 17.2148 & 81.2368 & 1.1730 & 1.2140 & 97.6030 & 0.1154 & 0.4370 & 99.4476 \\
\hline 15 & 0.6900 & 0.3617 & 98.9483 & 1.9438 & 18.2743 & 79.7818 & 1.4557 & 1.1088 & 97.4356 & 0.1698 & 0.5192 & 99.3111 \\
\hline 20 & 0.7968 & 0.3881 & 98.8151 & 2.1340 & 18.7314 & 79.1346 & 1.5655 & 1.0741 & 97.3603 & 0.2117 & 0.5676 & 99.2207 \\
\hline 25 & 0.8466 & 0.4004 & 98.7530 & 2.2356 & 18.9711 & 78.7934 & 1.6078 & 1.0615 & 97.3307 & 0.2388 & 0.5941 & 99.1671 \\
\hline
\end{tabular}



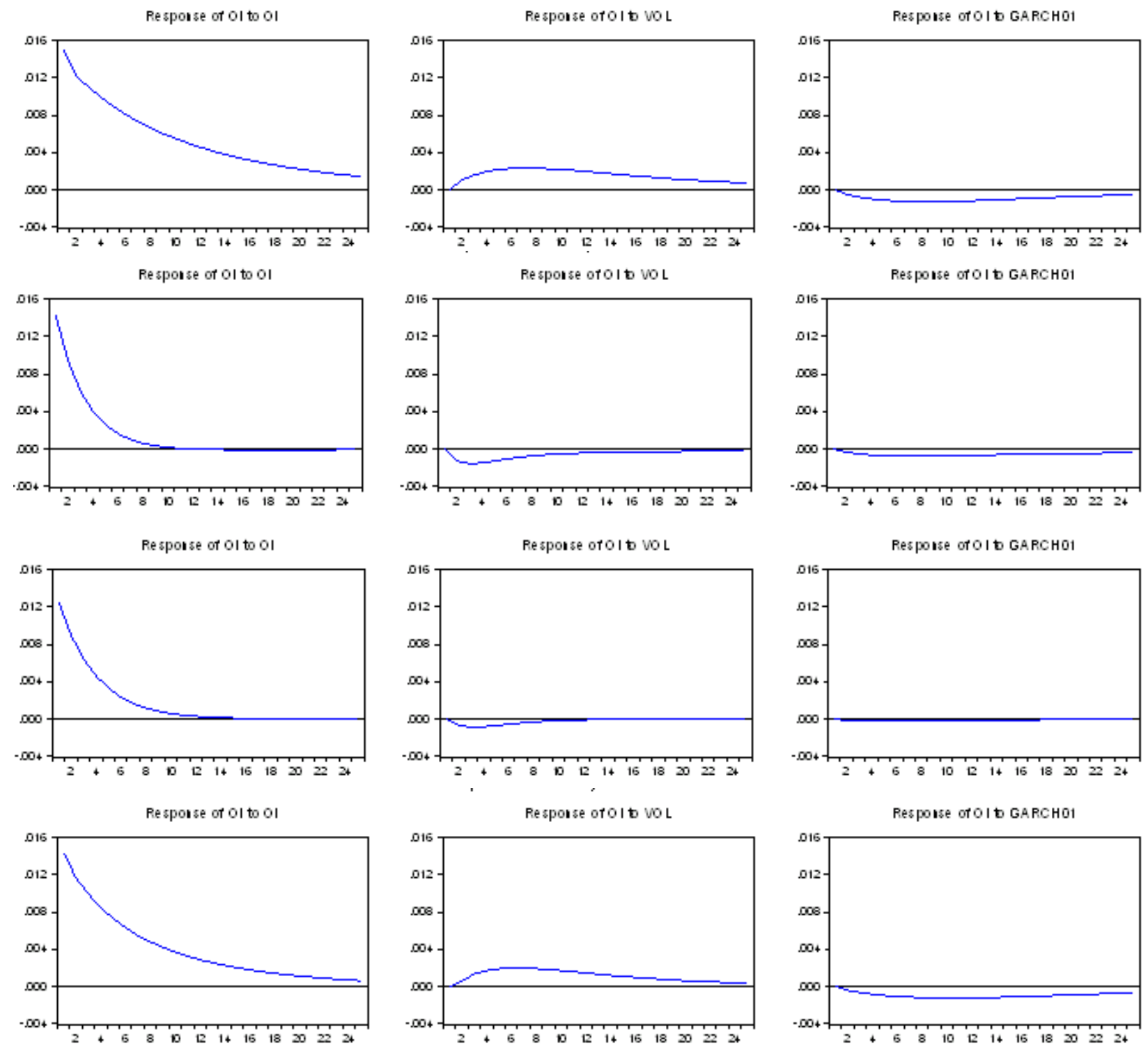

Fig. 2. Impulse response of open interest to shocks in volume and volatility over three sub-periods for contract size starting with 200 (first row), followed by 100 (second row), 50 (third row) and, finally, for the full period (fourth row).First, second and third column starting from left reflect impulse response of open interest toshocks of its own, volume and volatility, respectively 
Resporse orvol to ol

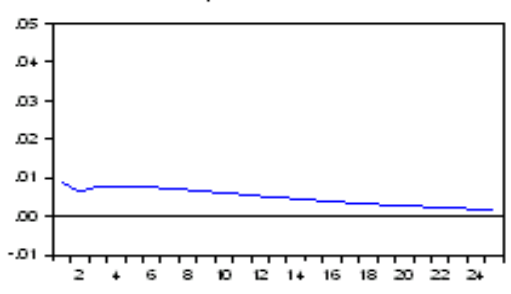

Resporse or VOL to

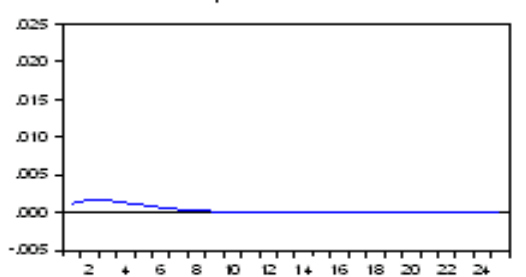

Resporse orVOL tor

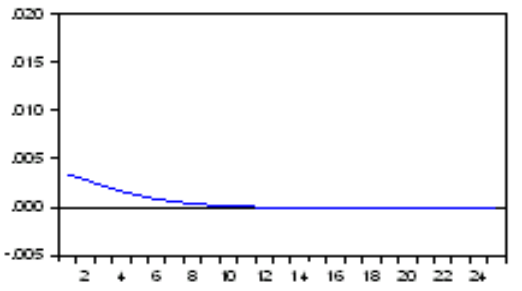

Resporse orvol tol

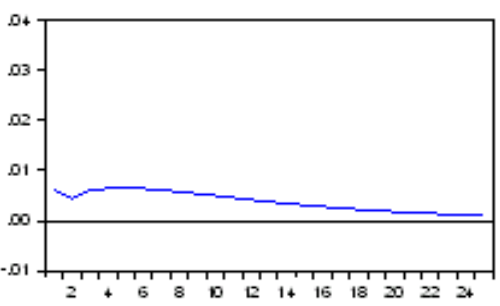

Resporse or vo $L$ to VoL

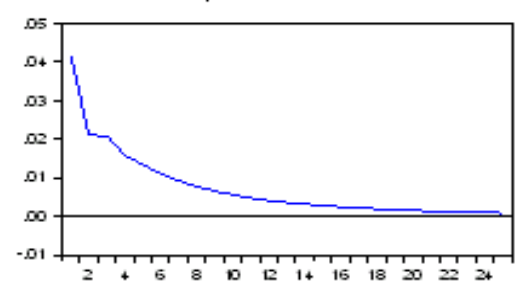

Re sporse of VOL to VOL

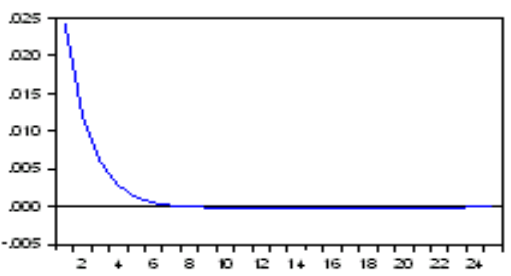

Resporse or VO L to VOL
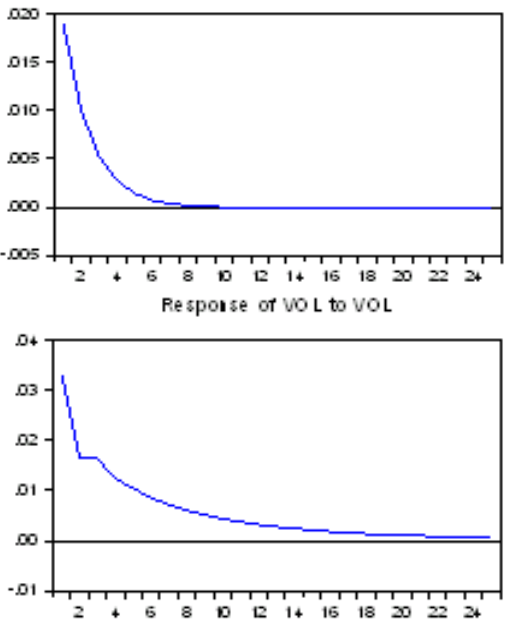

Pesponse or vol to GAPCHO

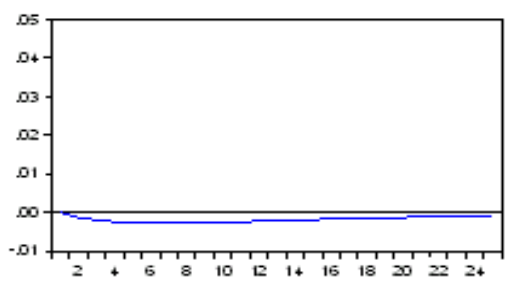

Resporse or VOL L GARCHO

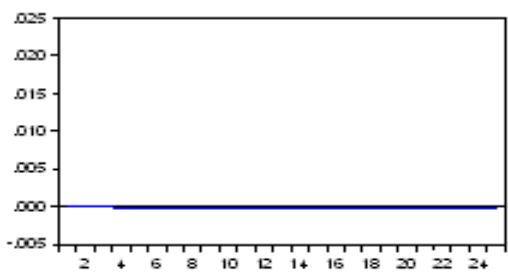

Resporse or VOL L GARC HO
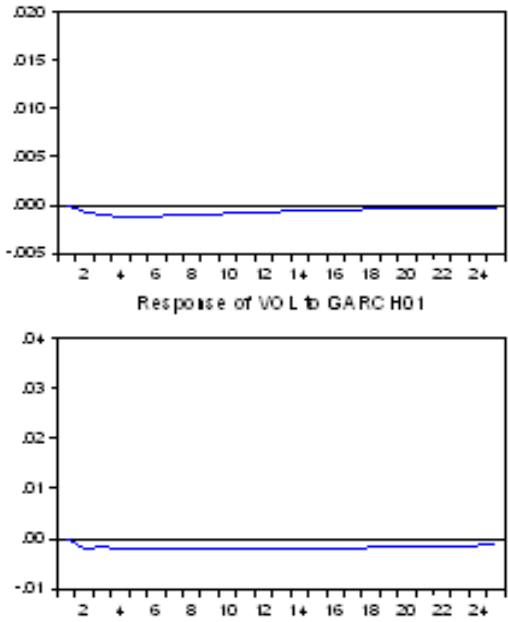

Fig. 3. Impulse response of volume to one unit positive shocks in open interest and volatility over three sub-periods for contract size starting with 200 (first row), followed by 100 (second row), 50 (third row) and finally for the full period (fourth row). First, second and third column starting from left reflect impulse response of volume to shocks of open interest, its own and volatility, respectively 

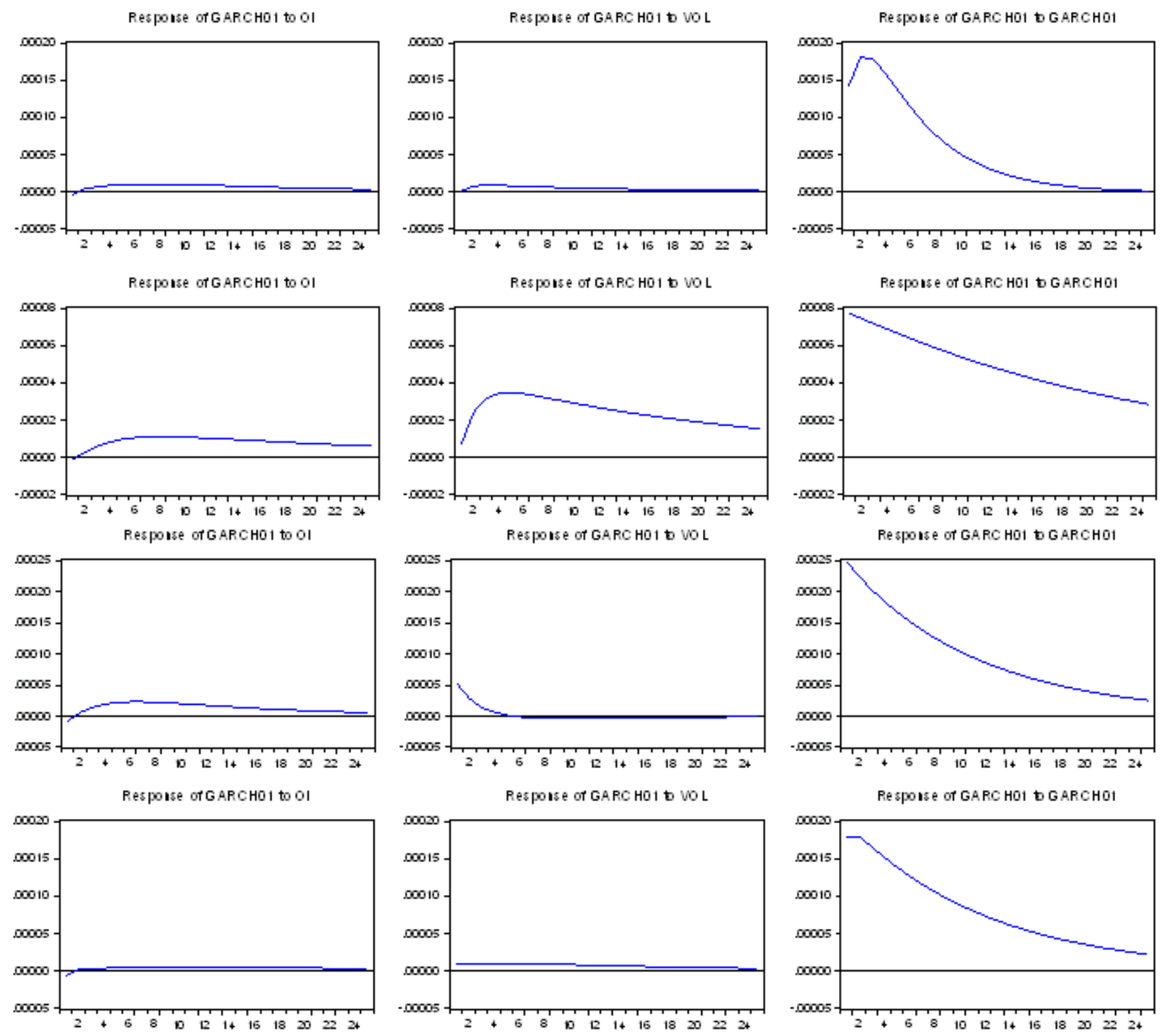

Fig. 4. Impulse response of volatility to shocks in volume and open interest of three sub-periods for contract size starting with 200 (first row), followed by 100 (second row), 50 (third row) and, finally, for the full period (fourth row). First, second and third column starting from left reflect impulse response of volatility to shocks of open interest, volume and its own, respectively 